http://dx.doi.org/10.11646/phytotaxa.190.1.3

\title{
The genus Ellisolandia (Corallinaceae, Corallinales, Rhodophyta) in the Azores (NE Atlantic): character expression and taxonomic evaluation
}

\author{
RUBEN P. COUTO ${ }^{12}$, EDGAR F. ROSAS-ALQUICIRA ${ }^{3},{\text { ARMINDO S. RODRIGUES }{ }^{4} \& \text { ANA I. NETO }}^{12}$ \\ ${ }^{I}$ CIRN - Centro de Investigação de Recursos Naturais and Departamento de Biologia, Universidade dos Açores, 9501-801 Ponta \\ Delgada, Apartado 1422, Portugal. \\ E-mail:coutoruben@uac.pt \\ ${ }^{2}$ CIIMAR - Centro Interdisciplinar de Investigação Marinha e Ambiental, Rua dos Bragas 289, 4050-123 Porto, Portugal \\ ${ }^{3}$ Instituto de Recursos, Universidad del Mar, 70902 Puerto Ángel, Oaxaca, México. \\ ${ }^{4}$ CVARG - Centro de Vulcanologia e Avaliação de Riscos Geológicos and Departamento de Biologia, Universidade dos Açores, $9501-$ \\ 801 Ponta Delgada, Apartado 1422, Portugal.
}

\begin{abstract}
Morphological and anatomical characters used for segregating species within the genus Corallina (Corallinaceae, Rhodophyta) have been compiled and evaluated in 120 specimens collected in the Azores. The morphological, anatomical and statistical evaluation of the thirty four segregating characters for the genus Corallina performed in the present study revealed no species segregation, either showing no differences across the whole lot of specimens or being highly variable within sets of plants. This suggests that all studied material belongs to one species, so far Ellisolandia elongata (formely Corallina elongata), thus reinforcing old proposed synonyms. A morphological and anatomical account is provided for this species, considering the whole set of studied specimens.
\end{abstract}

Key words: anatomy; Corallinales; Ellisolandia; morphology; segregating characters

\section{Introduction}

The genus Corallina Linnaeus (1758: 646, 805) (Corallinales, Rhodophyta) presently includes 30 currently accepted taxonomically species (Guiry \& Guiry 2013). The genus is widespread in tropical, subtropical and cool temperate areas, from the intertidal to shallow subtidal zones (Garbary \& Johansen 1982, Guiry \& Guiry 2013). Presently, the circumscription of the genus Corallina is not consensual (Brodie et al. 2013, Hind \& Saunders 2013). Hind \& Saunders (2013) established the genus Ellisolandia Hind \& Saunders (2013: 109) to encompass species with the morphological attributes of the genus Corallina but separated from it by mean of molecular phylogenetic characters. Although Ellisolandia has been circumscribed solely by mean of phylogenetic analyses, the authors affirm that no morphological characters distinguish the two genera. Brodie et al. (2013), however, proposed as epitype for Corallina elongata Ellis \& Solander (1786: 119) a specimen from south-west Devon, England and give a revised description for the species. In this study the need for further research to fully assess the range of morphological variation within and between species is strengthened. They made no comment on the new genus Ellisolandia.

In the present study, pending further advances, we will adopt the classification by Guiry \& Guiry (2013) and consider both genera separated.

The detailed diagnosis of Corallina is provided by Womersley \& Johansen (1996). As representative of the subfamily Corallinoideae (Areschoug) Foslie (1908: 19), the genus is characterized by the absence of secondary pit-connections and the presence of genicula composed of one tier of cells, and the cells of contiguous vegetative filaments being linked by cell fusions (Johansen 1981). Vegetative (Decaisne 1842, Beltrán \& Bárbara 2003) and reproductive characters (Johansen 1970, Kim et al. 2007) have been proposed for species diagnosis within Corallina but, as far as we know, no attempt has been made to evaluate their strength and reliability. 
This genus has been poorly studied, with few authors using a combination of morphological and anatomical characters for species circumscription (Johansen 1970, Bressan \& Benes 1977, Baba et al. 1988, Irvine \& Chamberlain 1994, Walker et al. 2009, Brodie et al. 2013).

No diagnosis of Ellisolandia has been published. This genus includes the single species Ellisolandia elongata (J.Ellis \& Solander) Hind \& Saunders (2013: 109) which has been flagged as currently accepted taxonomically (Guiry \& Guiry 2013). The species diagnosis for E. elongata made by Hind \& Saunders (2013) was based on the morphological characters proposed by Walker et al. (2009) for Corallina elongata.

In the Azores, five species of the former Corallina genus have been reported (Rosas-Alquicira et al. 2011). Piccone (1889) firstly recorded the genus in the archipelago by reporting the presence of $C$. officinalis Linnaeus (1758) on the Island of São Miguel. Four other species were subsequently recorded for the region, namely: $C$. granifera Ellis \& Solander (1786: 120) by Gain (1914), C. mediterranea Areschoug in Agardh (1852: 568) by Lemoine (1924), C. elongata Ellis \& Solander (1786: 119) by Castro \& Viegas (1983) and C. microptera Montagne (1846: 130) by Afonso-Carrillo \& Sansón (1999). According to Rosas-Alquicira et al. (2011) and Hind \& Saunders (2013), from the five species epithets reported from the Azores so far, just two are recognized as distinct species, namely $C$. officinalis and E. elongata ( $=$ C. elongata, C. mediterranea).

Nevertheless the diagnosis of these records was done in different occasions, by different persons and only based on external morphological features. Rosas-Alquicira et al. (2011) discussed the taxonomic relationship among the different Corallina species found in the archipelago and concluded that all species have yet to be fully reassessed through detailed vegetative and morfological studies. Brodie et al. (2013) achieved a similar opinion.

In the present paper a compilation of the published morphological and anatomical characters used in specieslevel taxonomic circumscription within Corallina is provided and their systematic value is assessed for 120 specimens collected in the Azores.

\section{Materials and Methods}

The published anatomical characters used in species circumscription within Corallina were compiled and grouped in four general categories: (1) substrate relationship; (2) morphological characters; (3) anatomical (vegetative) characters; and (4) reproductive (morphology and conceptacle anatomy) characters.

The studied material included 120 Azorean specimens, both new collections and herbarium collections from seven Azorean islands and Formigas Islets (Fig. 1). New specimens were collected in the intertidal zone, fixed in $4 \%$ formalin in seawater and stored in the Herbarium Ruy Telles Palhinha (AZB), Departamento de Biologia, Universidade dos Açores, Portugal. Historical collections included Azorean specimens from the Dutch oceanographic CANCAP V expedition housed in the National Herbarium of the Netherlands (Leiden - L). Herbarium abbreviations follow Thiers (2013).

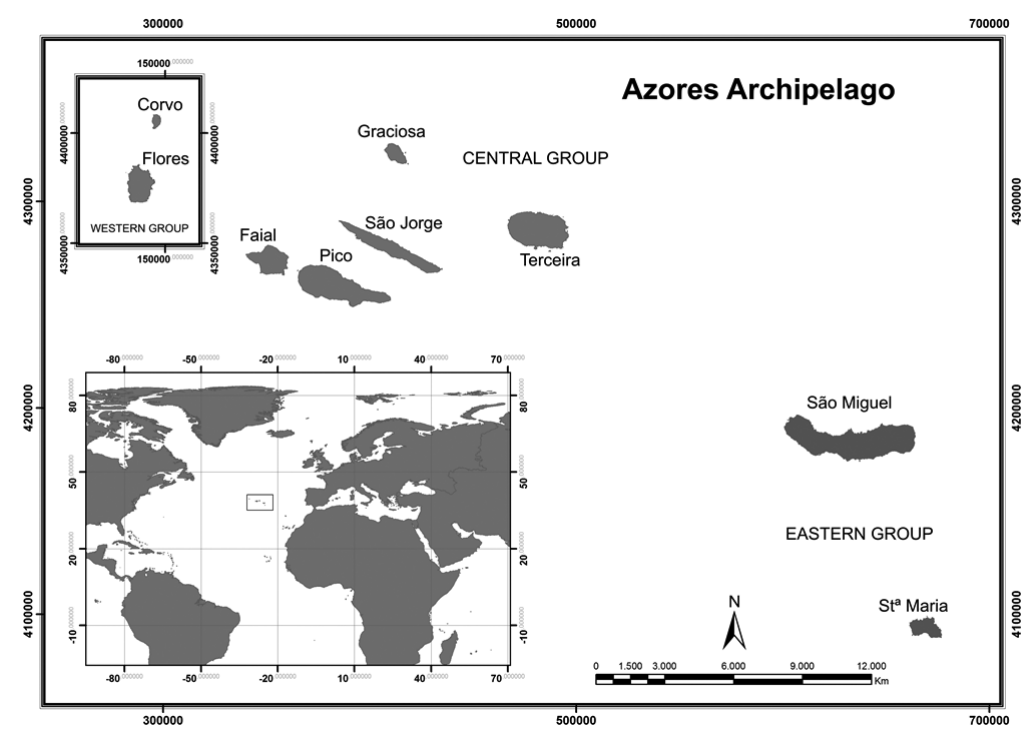

FIGURE 1. Archipelago of the Azores (by Nuno V. Álvaro). 
TABLE 1. Characters evaluated in Azorean Corallina specimens.

\begin{tabular}{lll}
\hline \# Character & Character states & References \\
\hline $\begin{array}{l}\text { 1. Substrate relationship } \\
\text { Vegetative morphology }\end{array}$ & Epilithic, epiphytic, epizoic, semiendophytic & {$[4][6][17]$} \\
2. Crustose base diameter (mm) & Highly variable & {$[6][10][18]$} \\
3. Plant size (mm) & Highly variable & {$[1][4][6][17][18]$} \\
4. Number of terminal intergenicula & Highly variable & {$[6][11]$} \\
5. Branching pattern & Regular, irregular & {$[6][17]$} \\
6. Branching planes & 1, more than 1 & {$[6][8]$} \\
7. Branching orders & Highly variable & {$[6][8]$} \\
8. Branching angle & $<45^{\circ},>45^{\circ}$ & {$[6][8]$} \\
9. Gaps between sucessive lateral branches & Conspicuous; inconspicuous & {$[6][10][18]$} \\
10. Branching density index & Highly variable & This study \\
11. Intergenicula shape & Terete to compressed, terete, compressed & {$[4][6][10][18]$} \\
12. Ultimate intergenicula laterally expanded & Yes, No & {$[7][16]$} \\
13. Ultimate intergenicula geminated (anastomosis) & Presence, absence & {$[1]$} \\
14. Intergenicula apices form & Rounded, blunt & {$[6][8]$} \\
15. $L$ - Intergenicular length (mm) & Highly variable & {$[3][4][6][10][11][18]$} \\
16. $L M$ - Intergenicular major width (mm) & Highly variable & {$[4][6][11]$} \\
17. Im - Intergenicular minor width (mm) & Highly variable & {$[5][6]$} \\
18. Length/Width intergenicular ratio & Highly variable & {$[4][8][18]$} \\
19. Morphometric index & Highly variable & {$[5]$} \\
\hline
\end{tabular}

\section{Vegetative anatomy}

20. Genicular length $(\mu \mathrm{m})$

Highly variable

$[3][6][10][18]$

21. Genicular width $(\mu \mathrm{m})$

Highly variable

[3][6][10][18]

22. Thickness of the cortex $(\mu \mathrm{m})$

Highly variable

[3][10] [18]

23. Cell rows in cortex

Highly variable

[3][10] [18]

24. Tiers of medullary cells

Highly variable

[8][10][18]

25 . Lenght of medullary cells $(\mu \mathrm{m})$

Highly variable

[9][10][18]

\section{Reproductive morphology}

26. Pedunculate conceptacles

27. Lateral conceptacles

28. Conceptacles with horns

29. Branched conceptacles

30. Position of conceptacles in thallus

Presence, absence

$[4][6][13][12][20]$

Presence, absence

[6][11]

Presence, absence

[2][12][13][14][15][17][19]

Presence, absence

[6][9][10]

End of: lateral branches, main branches

$[6][18]$

\section{Conceptacle anatomy}

31. Chamber diameter $(\mu \mathrm{m})$

Highly variable

$[3][10][18]$

32. External diameter $(\mu \mathrm{m})$

Highly variable

[3]

33. Chamber height $(\mu \mathrm{m})$

Highly variable

[3][10][18]

34. Pore canal length $(\mu \mathrm{m})$

Highly variable

References: [1] Adams (1994); [2] Ardré (1970); [3] Baba et al. (1988); [4] Beltrán \& Bárbara (2003); [5] Bressan \& Benes (1977); [6] Brodie et al. (2013); [7] Dawson (1953); [8] De-Clerck et al. (2005); [9] Gayral (1958); [10] Irvine \& Chamberlain (1994); [11] Johansen (1976); [12] Lamouroux (1816); [13] Lamouroux (1821); 14] Lawson \& John (1982); [15] Manza (1940); [16] Millar (1990); [17] Taylor (1967); [18] Walker et al. (2009);19] Yendo (1902); [20] Yendo (1905). 
Dimensional characters reported in previously published studies (Bressan \& Benes 1977, Irvine \& Chamberlain 1994, Bressan \& Babbini 2003, Walker et al. 2009, Brodie et al. 2013) were used for comparisons with the studied material from the Azores.

The morphometric index of Bressan \& Benes (1977) was used to evaluate morphological differences in intergeniculum shapes.

As the frequency of branching has been historically used to distinguished among the Corallina species (Irvine \& Chamberlain 1994, Beltrán \& Bárbara 2003), we applied a quantitative index to evaluate density differences in plants relating the number of branched intergenicula $(B I)$ at the main axis and the total number of intergenicula (TI) at the main axis. The Branching density index (BDI) elaborated is:

$\mathrm{BDI}=\frac{B I}{T I}$

A BDI value equal or close to one means that the analised plant is densely branched with almost no gaps between successive lateral branches.

The software PRIMER $6\left({ }^{\circledR}\right.$ PRIMER-E) was used to run Principal Component Analysis (PCA) and Non Parametric Analysis of Similarity (ANOSIM) for comparison of specimens based on normalized Euclidean distances (Clarke \& Warwick 2001). Highly correlated $(P<0.001)$, redundant morphological and anatomical features were identified through Pearson's correlation coefficient and those considered inappropriate were excluded from subsequent analyses (Hering et al. 2006, Feld \& Hering 2007).

\section{Results}

From the thirty four characters evaluated (Tab. 1), the qualitative ones were similar in all the specimens analysed (characters 1, 2, 5, 6, 8, 9, 11, 12, 13, 14, 26, 27, 28, 29 and 30: substrate relationship, crustose base diameter, branching pattern, branching planes, branching angle, gaps between sucessive lateral branches, intergenicula shape, ultimate intergenicula laterally expanded, ultimate intergenicula geminated, intergenicula apices form, pedunculate conceptacle, lateral conceptacles, conceptacles with horns, branched conceptacles and position of conceptacles in the thallus, see Tab. 2). The gaps between successive lateral branches were absent or insconspicuous in all studied specimens. The crustose base was variable in size but always larger than $10 \mathrm{~mm}$. The remaining characters, all quantitative, were also highly variable within a set of plants (Tab. 2).

The quantitative index BDI (branching density index) was 0.79 (see Table 2) indicating a main axis densily branched with reduced or inconspicuous gaps. A more detailed analysis revealed that more than $85 \%$ of the studied plants presented a BDI higher than 0.6 (Fig. 2).

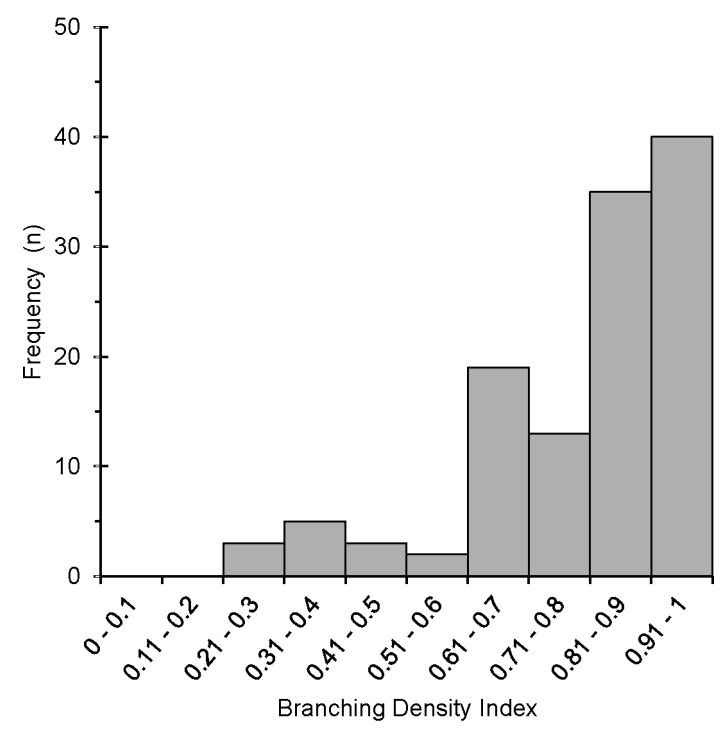

FIGURE 2. Frequency distribution of branching density index of the studied plants $(n=120)$. 


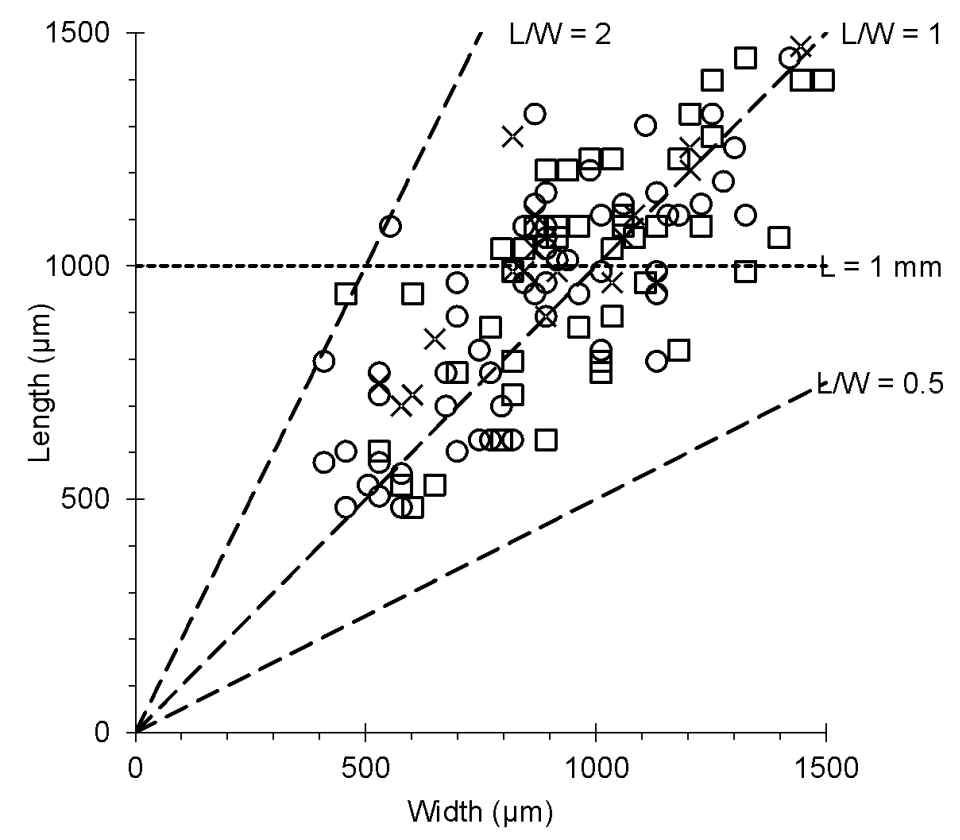

FIGURE 3. Intergenicula length (L) and width (W) of the studied plants respecting their classification pryor to this investigation: $\square-$ C. elongata $(\mathrm{n}=44), \times-$ C. officinalis $(\mathrm{n}=19)$ and $\circ-$ Corallina $\mathrm{sp}$. $(\mathrm{n}=57)$. LW - Length/Width ratio.

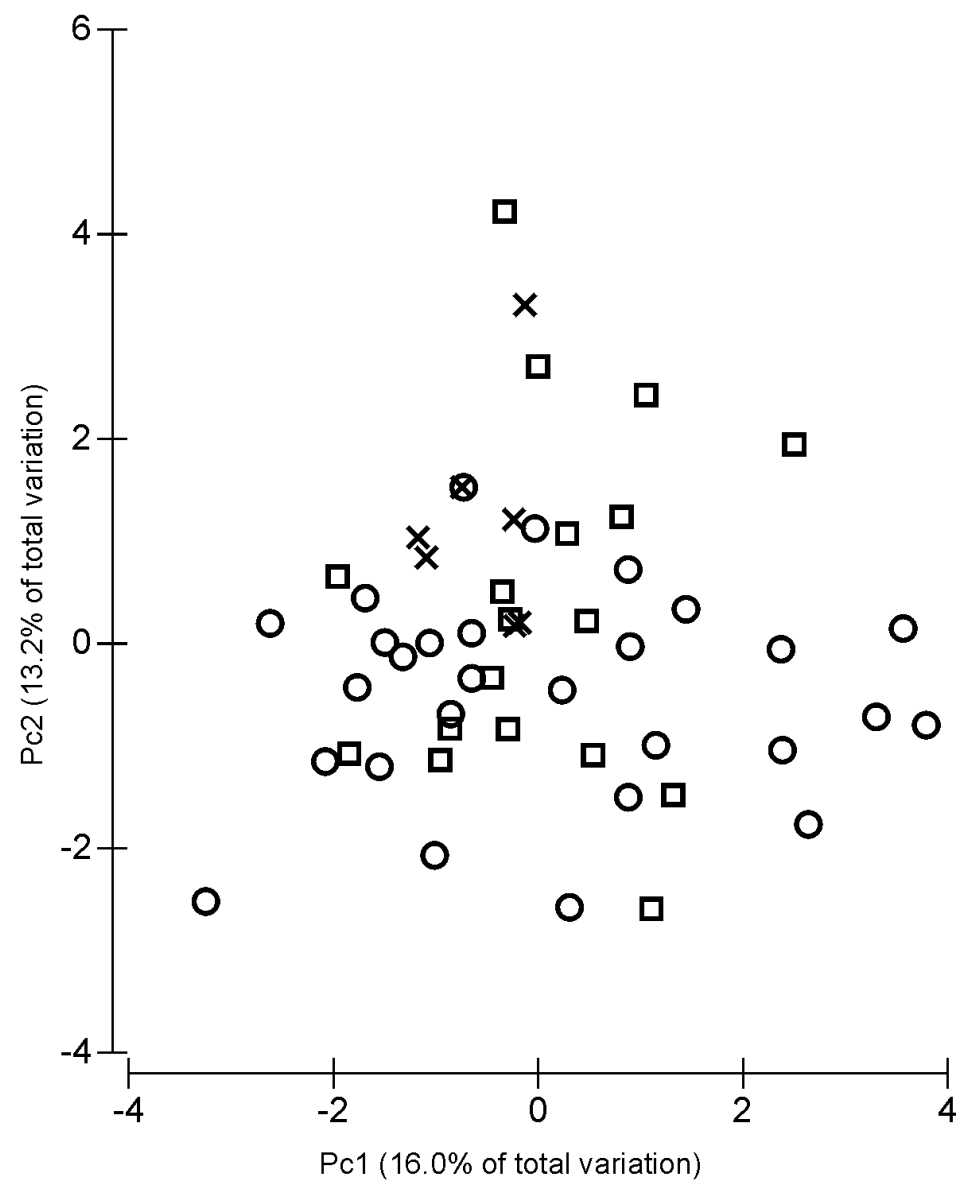

FIGURE 4. PCA scores plot showing clustering of the studied plants $(n=53)$ according to their morphological and anatomical characters (15 characters) trough two principal components axes (PC). $\square$ —Corallina elongata; $\times$ Corallina officinalis; ○—Corallina sp.

The tabulation of the intergenicular length and width of Azorean specimens (Fig. 2) shows a cloud of dots around the central axis ( $\mathrm{L} / \mathrm{W}=1$, equal length and width) and does not show any obvious segregating pattern. 
Following the Pearson correlation coefficient analyses, the characters 4, 6, 15-18, 21, 28, 32 and 33 (see Tab. $1)$, highly correlated $(P<0.001)$, were excluded from further analysis to avoid redundancy.

The PCA analyses of the remaining fifteen characters (Fig. 4) did not reveal any grouping patterns among the studied herbarium specimens, with the first two principal component axes only explaining $29.2 \%$ of the variation (Tab. 3).

The ANOSIM analysis of the same data did not present significant differences among sets of plants, showing a global significance level of $3.2 \%$ but a low $R$ value (0.101).

The above results suggest that all the studied material belongs to a single species: Ellisolandia elongata (formely Corallina elongata).

TABLE 3. Percentage of variation for each principal component (PC) axis.

\begin{tabular}{lll}
\hline PC axis & \% Variation & $\begin{array}{l}\text { Cumulative \% } \\
\text { Variation }\end{array}$ \\
\hline 1 & 16.0 & 16.0 \\
2 & 13.2 & 29.2 \\
3 & 10.5 & 39.8 \\
4 & 9.3 & 49.1 \\
5 & 7.9 & 57.0 \\
\hline
\end{tabular}

\section{Taxonomy}

Ellisolandia elongata (J.Ellis \& Solander) Hind \& Saunders (2013) (Fig. 5, Tab. 2)

Basionym:-Corallina elongata Ellis \& Solander (1786).

Lectotype:-Ellis's illustrations designated by Irvine \& Chamberlain (1994) in the absence of a specimen; illustrations: Ellis (1755).

Lectotype locality:- Cornwall, England (Irvine \& Chamberlain 1994).

Epitype:-Designated by Brodie et al. (2013) (BM001032350, Fig. 5): England: South Devon, Plymouth Sound, Renny Rocks, 8 March 2012, leg. Christine A. Maggs (J. Brodie specimen code: JBCorallina 2012-2), at lower littoral, N50:19:07, W4:07:18. Genbank accession numbers: JX315327 [cox1], and JX315328 [rbcL].

Epitype locality:- England: South Devon, Plymouth Sound, Renny Rocks.

Specimens examined:-Corvo Island: AZB, CRV-89-100; L 0650084. Flores Island: AZB, FLW-99-129; L 0650079; L 0650080; L 0650082. Graciosa Island: AZB, GRW-06-91; AZB, GRW-06-120; AZB, GRW-06-148; AZB, GRW-06-448a; AZB, GRW-06-595; AZB, GRW-06-678. Pico Island: AZB, PIX-07-297; L 0650073; L 0650081; L 0650083; L 0835861. Faial Island: L 0650085; L 0650086. São Jorge Island: AZB, SJG-07-06; AZB, SJG-07-19; AZB, SJG-07-47; AZB, SJG-07-64. São Miguel Island: AZB, SMG-90-109; AZB, SMG-90-124; AZB, SMG-94-278; AZB, SMG-96-98; AZB, SMG-96-142; AZB, SMG-97-322; AZB, SMG-98-697; AZB, SMG-98727; AZB, SMG-98-1085; AZB, SMG-98-1093; AZB, SMG-98-1281; AZB, SMG-98-1329; AZB, SMG-98-1368; AZB, SMG-98-1397; AZB, SMG-98-1474; AZB, SMG-98-1486; AZB, SMG-98-1505; AZB, SMG-98-1533; AZB, SMG-98-1561; AZB, SMG-98-1585; AZB, SMG-98-1599; AZB, SMG-98-1630; AZB, SMG-99-3; AZB, SMG-99-26; AZB, SMG-99-39; AZB, SMG-99-49; AZB, SMG-99-50; AZB, SMG-99-92; AZB, SMG-99-126; AZB, SMG-99-162; AZB, SMG-99-170; AZB, SMG-99-198; AZB, SMG-99-200; AZB, SMG-99-215; AZB, SMG-99-226; AZB, SMG-99-247; AZB, SMG-99-284; AZB, SMG-99-325; AZB, SMG-99-338; AZB, SMG-99375; AZB, SMG-99-401; AZB, SMG-99-406; AZB, SMG-99-429; AZB, SMG-99-464; AZB, SMG-99-467; AZB, SMG-99-487; AZB, SMG-99-488; AZB, SMG-99-561; AZB, SMG-99-610; AZB, SMG-99-657; AZB, SMG-99674; AZB, SMG-99-824; AZB, SMG-02-262; AZB, SMG-02-285; AZB, SMG-03-158; AZB, SMG-03-171; AZB, SMG-03-172; AZB, SMG-03-187; AZB, SMG-03-191; AZB, SMG-03-204; AZB, SMG-03-219; AZB, SMG-03232; AZB, SMG-03-248; AZB, SMG-03-289; AZB, SMG-08-02; AZB, SMG-08-03; AZB, SMG-08-04; AZB, SMG-08-05; L 0650072; L 0650074; L 0650075; L 0650076. Formigas Islets: L 0650044; L 0650077; L 0650078. 


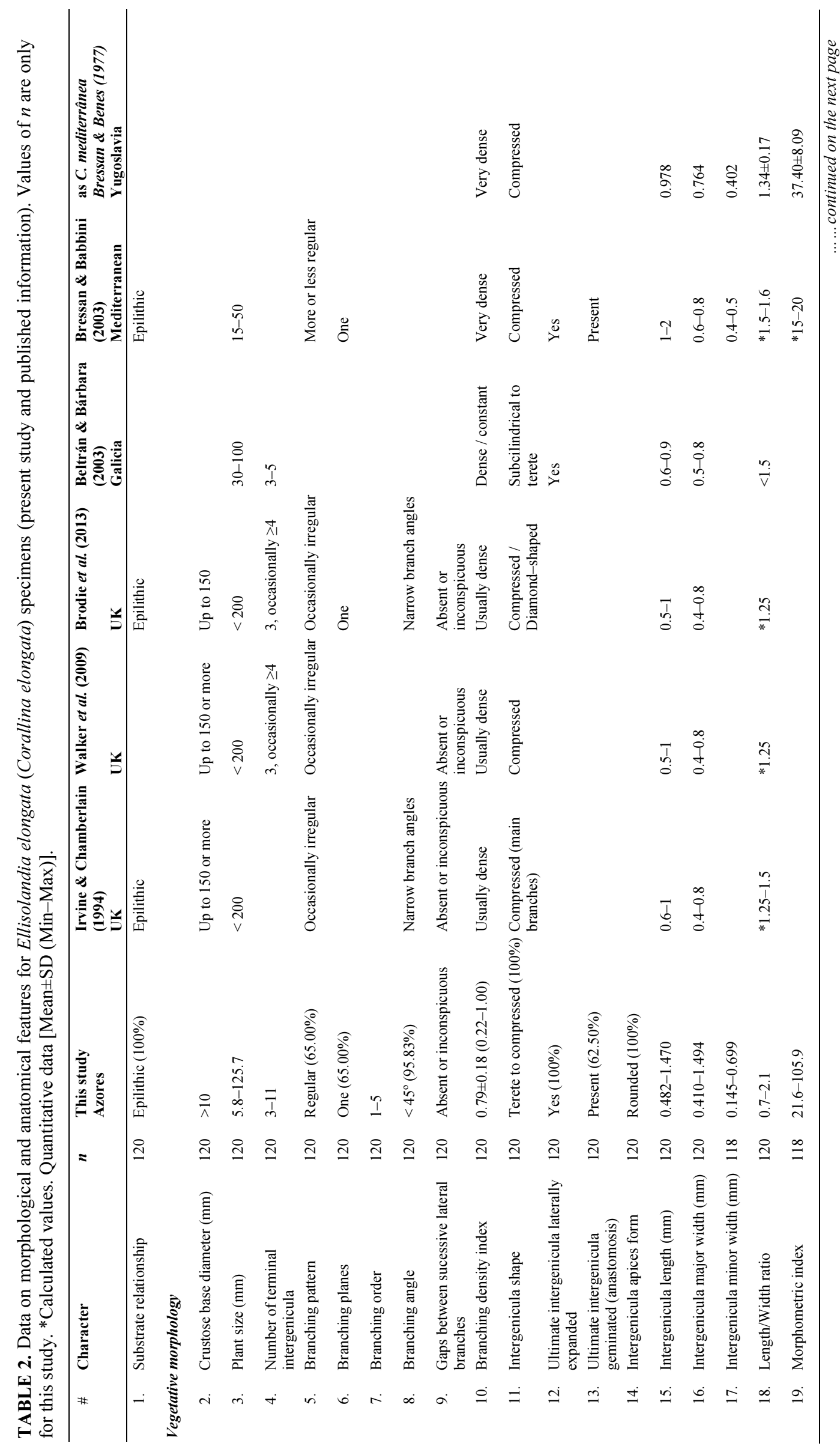




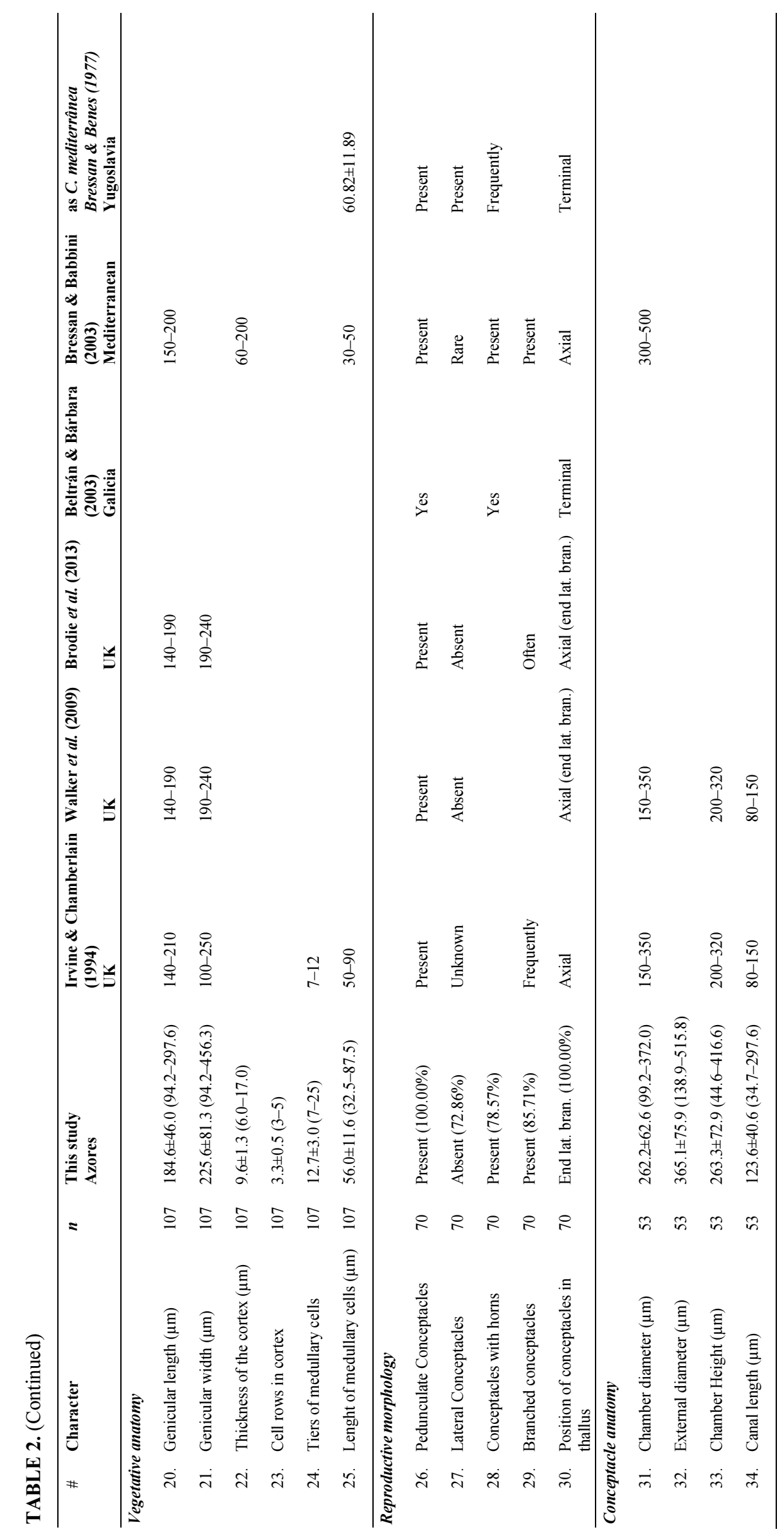


Description:- Thallus up to $125.7 \mathrm{~mm}$ high, consisting on geniculate fronds (Fig. 5a) attached by a crustose base variable in size but always larger than $10 \mathrm{~mm}$ and pinnately branched at the main axis (see Fig. 5a) with apices mostly rounded (Fig. 5b); stolons absent. Branching at narrow angles $\left(<45^{\circ}\right)$, originated at the genicula, gaps between successive lateral branches absent or incouspicuous, usually dense (mean BDI was 0.79), occasionally irregular $(35.00 \%)$. Fronds consisting of wedge shaped laterally expanded intergenicula, terete (at thallus base, Fig. 5c) to compressed (thallus apices, see Fig. 5a). These are 0.482-1.470 mm long and 0.410-1.494 $\mathrm{mm}$ in diameter at the main axis, tending to be nearly as wide as long (see Fig. 3, L/W ratio at Tab. 2); intergenicula composed of 7-25 tiers of medullary cells of 32.5-87.5 $\mu \mathrm{m}$. Geminated intergenicula (Fig. $5 \mathrm{~d}$ ) were common $(62.50 \%)$. Mature genicula composed by 1 tier of cells with $94.2-297.6 \mu \mathrm{m}$ long and $94.2-456.3 \mu \mathrm{m}$ in diameter. Cortex with 6-17 $\mu \mathrm{m}$ thick composed of 3-5 tiers of cells. Pedunculate conceptacles, mostly axial, sometimes also pseudolateral; conceptacles frequently bearing branches (Fig. 5f) and horns (Fig. 5e); tetrasporangial conceptacles 138.9-515.8 $\mu \mathrm{m}$ external diameter; tetrasporangial conceptacle chambers 99.2-372.0 $\mu \mathrm{m}$ diameter, 44.6-416.6 $\mu \mathrm{m}$ high with the roofs (canal length) 34.7-297.6 $\mu \mathrm{m}$ thick. Proliferous conceptacles (see Fig. 5f) frequently observed.

Distribution and habitat:-During the current study, Ellisolandia elongata was found intertidally in rock pools, sheltered crevices and to depths of $14 \mathrm{~m}$. Plants were epilithic. Ellisolandia elongata occurs in most tropical and subtropical regions, the Atlantic islands, the Mediterranean, the North-Western Europe and the South-Western Asia (Guiry \& Guiry 2013).

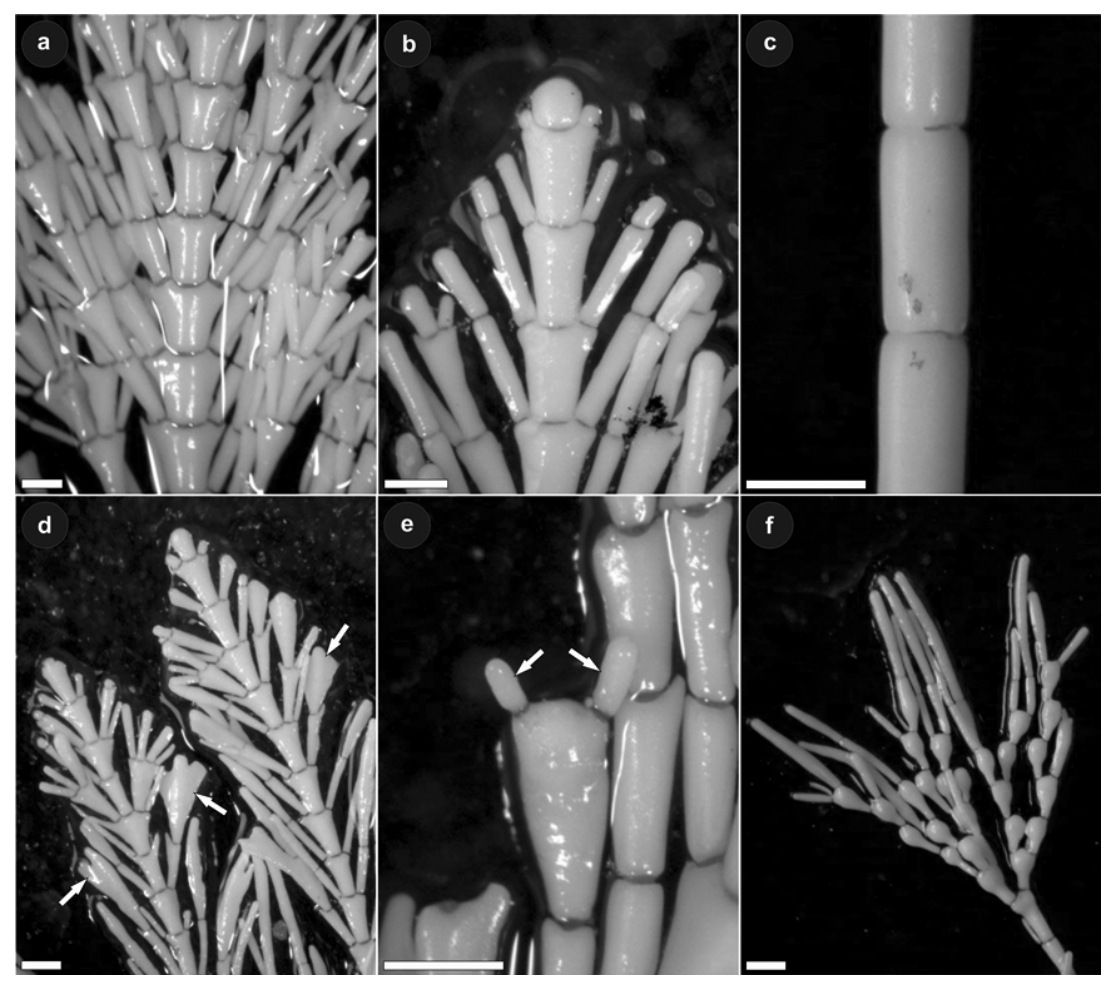

FIGURE 5. Ellisolandia elongata (by Ruben P. Couto). a. Geniculate, pinnately branched fronds. b. Round apices. c. Intergenicula terete. d. Geminated intergenicula (arrows). e. Horns (arrows). f. Branched conceptacles, proliferous. Scale bar $=0.5 \mathrm{~mm}$.

\section{Discussion}

From the five Corallina species listed to the archipelago (C. officinalis, C. granifera, C. mediterranea, C. elongata and $C$. microptera), only $C$. officinalis, the type species of the genus, is considered currently accepted taxonomically (Guiry \& Guiry 2013). C. microptera has an uncertain status as species, but is currently accepted in the Corallina genus (Rosas-Alquicira et al. 2011). C. elongata has recently been renamed as Ellisolandia elongata (Hind \& Saunders 2013). C. granifera has been considered a synonym of Haliptilon virgatum (Zanardini) Garbary \& Johansen (1982: 212), which is now considered a taxonomic synonym of Jania virgata (Zanardini) Montagne (1846: 133). C. mediterranea formely considered a synonym of $C$. elongata, is currently regarded as a taxonomic synonym of Ellisolandia elongata (Brodie et al. 2013). 
The morphological, anatomical and statistical evaluation of the thirty four species-level taxonomic characters for the genus Corallina applied in the 120 studied specimens revealed that either characters had the same expression in all the specimens analysed, or they were highly variable within a set of plants.

These results suggest that there is only one species present in the studied material reinforcing the old proposed synonyms (Bornet 1892, Irvine \& Chamberlain 1994, Prud'homme van Reine et al. 1994).

Considering that the majority of the characters observed in the studied specimens are closer to the ones described for E. elongata $(=C$. elongata, see Tab. 2), we propose that this is the species considered to be present in the studied material from the Azores. Characters supporting this conclusion include: a crustose base with variable size but always larger than $10 \mathrm{~mm}$, a feature that separates the studied material from C. caespitosa R.H.Walker, J.Brodie \& L.M.Irvine in (Walker et al. 2009: 290); gaps between successive lateral branches absent or incouspicuous and a length/width ratio around 1 (as wide as long), two features that separate the studied material from both C. caespitosa and C. officinalis (Irvine \& Chamberlain 1994, Walker et al. 2009, Brodie et al. 2013); a high branching density index; the presence of terete to compressed intergenicula; the ultimate intergenicula laterally expanded; the presence of conceptacles with horns; and the ultimate intergenicula geminated (anastomosis).

Our conclusion is in agreement with Prud'homme van Reine et al. (1994) that redefined as C. elongata the $C$. officinalis material collected in the Azores by Piccone (1889) and housed at Herbarium Patavinum (PAD) of the University of Padova. C. elongata was previously reported to the archipelago by several authors (Castro \& Viegas 1983, South \& Tittley 1986, Neto 1994, Prud'homme van Reine et al. 1994, Tittley \& Neto 1994, Neto 2000a, 2000b, Tittley \& Neto 2000, Toste et al. 2003, Wallenstein \& Neto 2006). However, it was not possible to review their studied specimens, a reason why we cannot consider them as synonyms of Ellisolandia elongata.

Specimens of Ellisolandia elongata (former C. elongata) from the Azores correspond to the morphological original description (Ellis \& Solander 1786) and the descriptions and illustrations of Bressan \& Benes (1977), Irvine \& Chamberlain (1994), Bressan \& Babbini (2003), Beltrán \& Bárbara (2003), Walker et al. (2009) and Brodie et al. (2013) for plants from United Kingdom and the Mediterranean Sea. In general, the range values for vegetative and reproductive characters of Azorean specimens overlap those recorded for plants from other locations (see Tab. 2).

It is worthmentioning, however, that specimens of the Azores morphologically identical to C. elongata as described in Walker et al. (2009) were found to be genetically identical to C. caespitosa (DQ191343, Hind \& Saunders 2013), a result that indicates that the morphological differentiation of the two species is still uncertain. This suggest that the accurate figure of the actual diversity of Corallina and the new genus Ellisolandia in this region and elsewhere in the world requires extensive work involving further collections, molecular evaluations complemented by detailed and exhaustive morphological descriptions of type material and studied specimens (Brodie et al. 2013, Hind \& Saunders 2013).

\section{Acknowledgements}

The authors thank to Francisco Wallenstein for the English revision. Ricardo Camarinho helped with histological procedures. Nicolien Sol (loans officer, at the National Herbarium of the Netherlands) provided historical collections. Nuno Álvaro provided the study area map. This work was funded by Centro de Investigação de Recursos Naturais da Universidade dos Açores (CIRN). Ruben P. Couto was supported by a PhD grant from the Regional Government of Azores (DRCT - M3.1.1/I/014A/2005) and by a Post-Doctoral funding (M3.1.7/F/006/ 2011) granted by FRC - Fundo Regional da Ciência (SRECC - Secretaria Regional da Educação, Ciência e Cultura, Regional Government of the Azores). The sampling procedures of the present study comply with the current laws of Portugal. 


\section{References}

Afonso-Carrillo, J. \& Sansón, M. (1999) Algas hongos y fanerógamas marinas de las Islas Canarias. Clave analítica. Universidad de La Laguna, La Laguna.

Agardh, J.G. (1852) Species Genera et Ordines FLORIDEARUM, seu Descriptiones Succinctae Specierum Generum Et Ordinum Quirus Floridearum Classis Constituitur. London. http://dx.doi.org/10.5962/bhl.title.1576

Baba, M., Johansen, H.W. \& Masaki, T. (1988) The segregation of three species of Corallina (Corallinales, Rhodophyta) based on morphology and seasonality in Northern Japan. Botanica Marina 31: 15-22. http://dx.doi.org/10.1515/botm.1988.31.1.15

Beltrán, M. \& Bárbara, I. (2003) Estudio morfológico comparado entre Corallina officinalis y C. elongata (Corallinales, Rhodophyta) en el noroeste de la Península Ibérica. Nova Acta Cientifica Compostelana (Bioloxía) 13: 5-16.

Bornet, M.É. (1892) Les algues de P.-K.-A. Schousboe recoltées au Maroc et dans la Méditerranée de 1815 a 1829. Mémoires de la Société des Sciences Naturelles et Mathématiques de Cherbourg 28: 165-376.

Bressan, G. \& Babbini, L. (2003) Biodiversità marina delle coste Italiane: Corallinales del Mar Mediterraneo: Guida alla determinazione. Biologia Marina Mediterranea 10(2): 1-237.

Bressan, G. \& Benes, M. (1977) Individuazione di caratteri quantitativi diacritici in Corallina mediterranea Areschoug e C. Officinalis Linneo (Corallinaceae-Rhodophyceae). Bollettino della Società Adriatica di Scienze 61: 1-10.

Brodie, J., Walker, R.H., Williamson, C. \& Irvine, L.M. (2013) Epitypification and redescription of Corallina officinalis L., the type of the genus, and C. elongata Ellis et Solander (Corallinales, Rhodophyta). Cryptogamie, Algologie 34(1): 49-56. http://dx.doi.org/10.7872/crya.v34.iss1.2013.49.

Castro, M.L.F. \& Viegas, M.C. (1983) Estudo de povoamentos de algas fotófilas da ilha de São Miguel (Açores). Arquipélago (Série Ciências da Natureza 4: 7-30.

Clarke, K.R. \& Warwick, R.M. (2001) Change in Marine Communities: An approach to statistical analysis and interpretation. PRIMER-E, Plymouth.

Decaisne, J. (1842) Mémoires sur les corallines ou polypiers calcifères. Annales des Sciences Naturelles, Botanique 2(16): 85-120.

Ellis, J. (1755) An Essay Towards a Natural History of the Corallines, And Other Marine Productions of the like Kind, Commonly Found On the Coasts of Great Britain and Ireland. Printed for the author, London, pp. 103. http://dx.doi.org/10.5962/bhl.title.10146

Ellis, J. \& Solander, D. (1786) The Natural History of Many Curious and Uncommon Zoophytes, Collected from Various Parts of the Globe. Benjamin White and Son, London. http://dx.doi.org/10.5962/bhl.title.64985

Feld, C.K. \& Hering, D. (2007) Community structure or function: effects of environmental stress on benthic macroinvertebrates at different spatial scales. Freshwater Biology 52: 1380-1399. http://dx.doi.org/10.1111/j.1365-2427.2007.01749.x

Foslie, M.H. (1908) Algologiske notiser V. Kongelige Norske Videnskabers Selskabs Skrifter, pp. 20.

Gain, L. (1914) Algues provenant des campagnes de "l Hirondelle" II" (1911-1912). Bulletin de l'Institut Oceanographique (Monaco) 279: 1-23.

Garbary, D.J. \& Johansen, H.W. (1982) Scanning electron microscopy of Corallina and Haliptilon (Corallinaceae Rhodophyta): surfaces features and their taxonomic implications. Journal of Phycology 18: 211-219. http://dx.doi.org/10.1111/j.1529-8817.1982.tb03176.x

Guiry, M.D. \& Guiry, G.M. (2013) AlgaeBase, World-wide electronic publication, National University of Ireland, Galway. Available from: http://www.algaebase.org (accessed: 21 October 2013).

Hering, D., Feld, C.K., Moog, O. \& Ofenböck, T. (2006) Cook book for the development of a Multimetric Index for biological condition of aquatic ecosystems: experiences from the European AQEM and STAR projects and related initiatives. Hydrobiologia 566: 311-324.

Hind, K.R. \& Saunders, G.W. (2013) A Molecular Phylogenetic Study of the Tribe Corallineae (Corallinales, Rhodophyta) with an Assessment of Genus-Level Taxonomic Features and Descriptions of Novel Genera. Journal of Phycology 49(1): $103-114$. http://dx.doi.org/10.1111/jpy.12019

Irvine, L.M. \& Chamberlain, Y.M. (1994) Seaweeds of the British Isles. Vol. 1. Rhodophyta. Part 2B. Corallinales, Hildenbrandiales. Natural History Museum, London, pp. 276.

Johansen, H.W. (1970) The diagnostic value of reproductive organs in some genera of articulated Coralline red algae. European Journal of Phycology 5(1): 79-86. http://dx.doi.org/10.1080/00071617000650101

Johansen, H.W. (1981) Coralline Algae, A First Synthesis. Florida.

Kim, J.H., Guiry, M.D., Oak, J.H., Choi, D.-S., Kang, S.-H., Chung, H. \& Choi, H.-G. (2007) Phylogenetic relationships within the tribe Janieae (CORALLINALES, RHODOPHYTA) based on molecular nand morphological data: a reappraisal of Jania. Journal of Phycology 43: 1310-1319. http://dx.doi.org/10.1111/j.1529-8817.2007.00410.x

Lemoine, P. (1924) Corallinacées du Moroc (1). Bulletin de la Société des Sciences Naturelles de Maroc 4: 113-134.

Linnaeus, C. (1758) Systema naturae per regna tria naturae. Laurentii Salvii, Stockholm. http://dx.doi.org/10.5962/bhl.title.542

Montagne, C. (1846) Flore d`Algèrie. Ordo I. Phyceae Fries In Exploration scientifique de l'Algérie pendant les années 1840, 1841, 1842. Sciences physiques. Botanique. Cryptogamie., ed Durieu De Maisonneuve, M.C. (Imprimerie Royale, publiée par ordre du 
Gouvernement et avec le concours d'une Commission Académique., Paris), Vol 1, pp. 197.

Neto, A.I. (1994) Checklist of the benthic marine macro algae of the Azores. Arquipélago. Life and Marine Sciences 12(A): 15-34.

Neto, A.I. (2000a) Ecology and dynamics of two intertidal algal communities on the littoral of the island of São Miguel (Azores). Hydrobiologia 432: 135-147.

Neto, A.I. (2000b) Observations on the biology and ecology of selected Macroalgae from the Littoral of São Miguel (Azores). Botanica Marina 43: 483-498.

Piccone, A. (1889) Alghe della Crociera del alle Azzorre. Nuovo giornale botanico italiano 21: 171-214.

Prud'homme van Reine, W.F., Haroun, R.J. \& Audiffred, P.A.J. (1994) A reinvestigation of Macaronesian seaweeds as studied by A. Piccone with remarks on those studied by A. Grunow. Nova Hedwigia 58: 67-121.

Riosmena-Rodríguez, R., Woelkerling, W.J. \& Foster, M.S. (1999) Taxonomic reassessment of rhodolith-forming species of Lithophyllum (Corallinales, Rhodophyta) in the Gulf of California, Mexico. Phycologia 38(5): 401-417. http://dx.doi.org/10.2216/i0031-8884-38-5-401.1

Rosas-Alquicira, E.F., Riosmena-Rodríguez, R., Afonso-Carrillo, J. \& Neto, A.I. (2011) Taxonomic biodiversity of geniculate coralline red algae (Corallinales, Rhodophyta) from the Macaronesian region: summary and analysis. Helgoland Marine Research 65(2): 133-153. http://dx.doi.org/10.1007/s10152-010-0209-0.

South, G.R. \& Tittley, I. (1986) A checklist and distributional index of the benthic marine algae of the North Atlantic Ocean. Huntsman Marine Laboratory and British Museum (Natural History), St. Andrews and London.

Thiers, B. (2013) Index herbariorum: a global directory of public herbaria and associated staff., New York Botanical Garden's Virtual Herbarium, New York Available from: http://sweetgum.nybg.org/ih/ (accessed: 21 October 2013).

Tittley, I. \& Neto, A.I. (1994) "Expedition Azores 1989": benthic marine algae (seaweeds) recorded from Faial and Pico. Arquipélago. Life and Marine Sciences 12(A): 1-13.

Tittley, I. \& Neto, A.I. (2000) A provisional classification of algal-characterised rocky shore biotopes in the azores. Hydrobiologia 440:19-25. http://dx.doi.org/10.1007/978-94-017-1982-7 2

Toste, M.F., Parente, M.I., Neto, A.I. \& Fletcher, R.L. (2003) Life history of Colpomenia sinuosa (Scytosiphonaceae, Phaeophyceae) in the Azores. Journal of Phycology 39:1268-1274. http://dx.doi.org/10.1111/j.0022-3646.2003.02-049.x

Walker, R.H., Brodie, J., Russell, S. \& Irvine, L.M. (2009) Biodiversity of coralline algae in the Northeastern Atlantic including Corallina caespitosa sp. nov. (CORALLINOIDEAE, RHODOPHYTA). Journal of Phycology 45: 287-297. http://dx.doi.org/10.1111/j.1529-8817.2008.00637.x.

Wallenstein, F.F.M.M. \& Neto, A.I. (2006) Intertidal rocky shore biotopes of the Azores: a quantitative approach. Helgoland Marine Research 60(3): 196-206. http://dx.doi.org/10.1007/s10152-006-0035-6

Womersley, H.B.S. \& Johansen, H.W. (1996) Subfamily Corallinoideae. In The Marine benthic Flora of Southern Australia-Part IIIB. Gracilariales Rhodymeniales Corallinales and Bonnemaisoniales., ed Womersley, H.B.S. (Canberra Australian Biological Resources Study, Australia), pp. 288-317. 